Ministerstwo Nauki

i Szkolnictwa Wyższego

Digitalizacja archiwalnych numerów czasopisma naukowego Analecta Cracoviensia 1-24 (1969-1992)

i ich publikacja w otwartym dostępie - zadanie finansowane w ramach umowy 672/P-DUN/2017 ze środków Ministra Nauki i Szkolnictwa Wyższego przeznaczonych na działalność upowszechniającą naukę

\title{
HENRYK KUPISZEWSKI
}

\section{POWTÓRNE MAEŻENSSTWO W KONSTYTUCJACH CESARZY RZYMSKICH W IV I V WIEKU*}

W nauce współczesnej prawa rzymskiego upowszechniony jest pogląd, że na stosunek legislatorów poklasycznych (od cesarza Konstantyna począwszy) do ponownie zawartego związku małżeńskiego, do secundae nuptiae, przemożny wpływ wywarła nauka Kościoła, formowana w IIIV wieku przez Ojców Kościoła.

Kościół ponownych związków małżeńskich nie zakazywał, ale odnosił się do nich z dezaprobatą. Pisarze chrześcijańscy i Ojcowie Kościoła inspirowani przez Ewangelię zalecali czystość, umiarkowanie, powściągliwość i umartwianie się. Nakazywali szacunek dla zmarłego małżonka. Ponowne małżeństwo, jako niezgodne z tymi zaleceniami, stanowczo odradzali. Stan wdowieństwa otoczyli szacunkiem, dostojeństwem i powagą. Nauka Kościoła, w której zresztą rysowały się tendencje bardziej skrajne i bardziej liberalne, znalazła wyraz w odpowiednich postanowieniach pierwszych synodów 1 .

* W roku 1969 Wiktor Panecki napisał pod moim kierunkiem prace magisterska Secundae nuptiae w prawie rzymskim, której część końcowa została w 1971 opublikowana pt. Secundae nuptiae $w \dot{z} y c i u$ i prawie starożytnych chrześcijan (.,Prawo kanoniczne”, 14, z. 1-2, 253-265). Pogląd, jaki na podstawie lektury źródeł przy tej okazji wyrobiłem sobie na zagadnienie secundae nuptiae w konstytucjach cesarskich IV i V w. przedstawiałem w marcu 1973 w Institut du Droit Romain w $\mathrm{Pa-}$ ryżu i w kwietniu tegoż roku na Wydziale Prawa w Uniwersytecie w Salzburgu. Nieco wcześniej, bo z końcem 1972 ukazała się znakomita książka uczonego francuskiego Michel Humbert, Remariage à Rome. Étude d'histoire juridique et social, Milano Giuffrè. Tak z uwagi na zakres czasowy - przedmiotem analizy są secundae nuptiae w czasach najdawniejszych, republikańskich, i w czasach cesarstwa aż do Justyniana - jak bogactwo problemów prawnych i socjalnych, zasługuje to dzieło na szczególną uwagę. Poświęcamy jej obszerne omówienie, które ukaże się w najbliższym tomie "Zeitschrift der Sav. Stieftung”.

1 Naukę Ojców Kościola o secundae nuptiae przedstawiają H. Insadowski, Rzymskie prawo małżńskie a chrześcijaństwo, Lublin, 1935, $310 \mathrm{nn}$. . J. Gaudemet, L'Eglise dans l'empire romain (IVe_Ve siècles), Paris 1958, 546 n., W. Panecki, art. cyt., 254., a przede wszystkim M. Humbert, dz. cyt., $310 \mathrm{nn}$. Autor przedstawił wszechstronnie naukę Ojców Kościoła, dając wyraz różnym tendencjom, jakie się w odniesieniu do secundae nuptiae rysowały, a także naukę Kościoła. 
Nauka Ojców Kościoła stała się dla wielu historyków prawa pryzmatem, przez który patrzą na rozwój stosunków prywatno-prawnych w cesarstwie rzymskim od czasów Konstantyna; stała się jedną z ważniejszych dyrektyw interpretacyjnych konstytucji cesarskich de secundis nuptiis.

Spośród uczonych, którzy w ostatnich czasach zajmowali się tą problematyką, dał temu wyraz H. Insadowski, który w monografii Rzymskie prawo malżeńskie a chrześcijaństwo konstatuje nieprzychylne stanowisko cesarzy względem małżeństw ponownych ${ }^{2}$. Podobne stanowisko zajął B. Biondi $\mathrm{w}$ imponującym dziele $\mathrm{Il}$ diritto romano cristiano ${ }^{3}$. Jasno również w naszej kwestii wypowiedział się M. Kaser: „Die Eingehung einer neuen Ehe nach Auflösung der ersten, von Augustus seinerzeit aus bevölkerungs- und sozialpolitischen Gründen zur Pflicht gemacht, wird in der nachklassischen Zeit geradezu nicht verboten aber doch missibilligt. Diese Umkehr beruht ebenso wie die Scheidungsbeschränkungen auf der christlichen Lehre von der unauflöslichen Wirkung der Ehe" 4 . O hostilitas cesarzy do powtórnego małżeństwa pisze także M. Humbert 5 .

Dopatrywanie się wpływów chrześcijaństwa w stosunku cesarzy do secundae nuptiae idzie w mej opinii za daleko. Konstytucje cesarskie, zestawione $\mathrm{w}$ kodeksie teodozjańskim i justyniańskim pod tytułami de secundis nuptiis ${ }^{5 a}$ mają na celu przede wszystkim, jeśli nie wyłącznie, ochronę interesów majątkowych dzieci z pierwszego małżeństwa. Ochrona tych interesów zasadza się na tym, że majątek zmarłego małżonka winien przypaść jego dzieciom w sytuacji, kiedy pozostały przy życiu małżonek zawiera ponowny związek małżeński. Pozostały przy życiu małżonek może wraz z dziećmi korzystać z majątku zmarłego tak długo, jak długo nie zawrze nowego małżeństwa. Jeśli zawrze drugie małżeństwo, przysporzenia majątkowe od zmarłego tracą moc, a właścicielami takiej masy majątkowej stają się dzieci zmarłego. Inaczej ma się zgoła rzecz, jeżeli małżonkowie w momencie śmierci jednego $\mathrm{z}$ nich dzieci nie posiadali. W takiej sytuacji, a więc kiedy interesy majątkowe dzieci $\mathrm{z}$ pierwszego małżeństwa nie wchodzą $\mathrm{w}$ rachubę - jest dla prawa obojętne, czy pozostały przy życiu małżonek zawrze nowy związek małżeński czy nie. W każdym razie nie dotyczą go żadne dyspozycje majątko-

2 Por. 315 nn.

3 Por. vol. 3, Milano 1954, 139.

4 Por. M. Kaser, Das römische Privatrecht (w dalszym ciągu: RPR) 2, München 1959, 124. Tam też zestawienie dalszej literatury w uw. 1 i 2.

5 Dz. cyt., $360 \mathrm{nn}$. Na podkreślenie wszakże zasługuje okoliczność, że Humbert zwrócił dużą uwagę na sytuację prawną dzieci w prawie klasycznym i że secundae nuptiae w IV-VI wieku rozpatruje w aspekcie kontynuacji przez cesarzy rozwoju zapoczątkowanego o epoce klasycznej prawa, oraz wpływów Kościoła od czasów Konstantyna. - Na ochronę interesów majątkowych dzieci w konstytucjach de secundis nuptiis zwrócił uwagę W. Panecki, art. cyt., 262.

5a CT 3.8; CJ 5.9 . 
we, które miałyby zastosowanie, gdyby były dzieci z pierwszego małżeństwa i które właśnie $\mathrm{w}$ rubrykach de secundis nuptiis są eksponowane. Informuje nas o tym w sposób nie budzący żadnych wątpliwości fragment konstytucji Gracjana, Walentyniana i Teodozjusza z r. 382 (CJ 5.8.3.2): „Quod si nulla (scil. mulier) ex priore matrimonio habuerit successionem vel natus native decesserint, omne, quod quoquo modo percepit, pleni proprietate iuris obtineat atque ex his nanciscendi dominii et testandi circa quem voluerit liberam habeat potestatem".

Samo małżeństwo lub ponowne małżeństwo, wbrew tytułom tych rubryk, pozostaje na dalszym planie. Więcej nawet! Przy lekturze konstytucji zestawionych $\mathrm{w}$ tytułach de secundis nuptiis ma się wrażenie, że takie frazy: „Feminae [...] quae ad secundas... transierint nuptias” (C.J 5.9 .3 pr.), „Itaque si habens filios in secundas nuptias fortasse transierit" cunda vel tertia aut ulterius repetiti matrimonii vota migraverit" (CJ (CJ 5.9.4.1), „Vir ad alias nuptias venit” (CJ 5.9.5.6), ,...Pater vel mater ad secunda vel tertia aut ulterius repetiti matrimonii vota migraverit" (CJ 5.9.6 pr.), nie tylko nie zawierają ujemnej oceny faktu zawarcia drugiego lub dalszego związku małżeńskiego, ale mają na celu zawsze i jedynie poinformowanie, że $w$ dalszym ciągu chodzi o ten sam stan faktyczny, o tę samą sytuację - ochronę interesów majątkowych, czy nawet szerzej, cchronę interesów dzieci w ogóle na przypadek, kiedy pozostały przy życiu małżonek wstępuje w ponowne związki małżeńskie.

Powstaje zatem pytanie, czym tłumaczyć ową szczególną troskę legislatorów poklasycznych o szeroko pojęte interesy dziecka, jeśli wbrew opinii wielu współczesnych uczonych odrzucimy lub wydatnie ograniczymy możliwość wpływów doktryny Ojców Kościoła.

Wydaje się, że odpowiedź na takie pytanie daje ewolucja, jaką rodzina rzymska przemierzyła od czasów najdawniejszych poprzez prawo klasyczne aż do Dioklecjana. Odpowiedź na to pytanie przynosi rozwój uprawnień osobowych i majątkowych, w jakie prawo na różnych etapach swego rozwoju wyposażało poszczególnych członków familia Romana. Konstantyn i jego następcy, w zmienionych co prawda warunkach i przy pomocy innej techniki prawnej ${ }^{6}$ niż jurysprudencja klasyczna, tę linię rozwojową kontynuowali. Warto może nakreślić zarys generalny tego rozwoju.

Rodzina rzymska jawi się w najdawniejszych źródłach, jakimi dysponujemy, jako grupa agnatyczna poddana silnej władzy naczelnika pater familias ${ }^{7}$. Prerogatywami tej władzy są ius vitae necisque, ius ven-

${ }_{6}$ Por. J. Gaudemet, La formation du droit seculier et du droit de l'Église, Paris $1957,11 \mathrm{nn}$.

7 Por. Max Kaser, RPR $1^{2}$ München 1971, 58 i tam cyt. lit. 
dendi, ius exponendi, ius coercendi, ius noxae dedicionis, exheredationis etc. ${ }^{8}$. Pater familias jest podmiotem wszystkich praw majątkowych ${ }^{9}$.

Od najwcześniejszego jednak okresu historii rodziny w Rzymie obserwuje się proces powolnej emancypacji jej poszczególnych członków i powolnego ograniczania prerogatyw ojcowskich. Przebiega on różnie w odniesieniu do różnych osób - członków familia.

Uxori in manu przyznało prawo skromne miejsce filiae et sororis loco ${ }^{10}$. Jej sytuacja prawna była prawie identyczna $\mathrm{z}$ sytuacją filia. Matrimonia jednak, którym nie towarzyszyło nabycie manus męża nad żoną, zrazu sporadyczne, upowszechniły się, by u schyłku reubliki, a może dopiero w pierwszym wieku cesarstwa, stać się typem małżeństwa jedynym ${ }^{11}$. Małżeństwo sine manu zmieniło wydatnie sytuację osobistą kobiety. Miało to także daleko idące reperkusje w prawie majątkowym. Jeśli kobieta była sui iuris - powstawała rozdzielność majątkowa małżeńska ${ }^{12}$ i, co za tym idzie, podstawą egzystencji rodziny był majątek tak męża, jak i żony. Na przypadek spadkobrania powstawały dwie masy majątkowe, bona paterna i bona materna, które w prawie spadkowym epoki klasycznej odrębnymi poczęły chodzić drogami. Małżeństwo sine manu dawało kobiecie możliwość rozwodu. W związku z tym i posag zmienił swoją funkcję ${ }^{13}$. Podczas gdy w małżeństwie cum manu służył ad onera matrimonii sustinenda, stał się z biegiem czasu także sposobem majątkowego zabezpieczenia kobiety na wypadek rozwodu. Wydaje mi się natomiast nader wątpliwe, by w jakimkolwiek okresie rozwoju prawa rzymskiego posag służył do zabezpieczenia trwałości związku małżeńskiego, jak tego usiłuje ostatnio dowieść A. Söllner ${ }^{14}$. Trwałość związku małżeńskiego $\mathrm{w}$ większym bowiem stopniu uzależniona jest od panujących poglądów obyczajowych, prawnych przekonań religijnych niż od elementów natury majątkowej.

s E. Sachers, RE 22, 1 Stuttgart szp. 1046 nn. s.v. patria potestas.

9 Por. T. Giaro, Własność $w$ Rzymie republikańskim (CPH 25, 2 Poznań 1973, 233 nn.) i tam cyt. lit.

10 Por. Gai. 1, 111; 1, 114; 2, 159; M. Kaser, dz. cyt., 79 n.

11 Por. dyskusję na temat zniknięcia matrimonium cum manu: J. Gaudemet Observation sur la manus (RIDA 2, Bruxelles 1953, 325 nn.); O. Robleda, El matrimonio en derecho romano, Roma 1970, $55 \mathrm{nn}$.

12 M. Garcia-Garrido, Ius uxorium, Roma 1958, 31 nn., 162 nn.; M. Kaser, RPR $1^{2}, 321 \mathrm{i}$ dalsza lit. w uw. 1 .

13 Por. M. Kaser, dz. cyt., 332 n. i tam dalsza lit.

14 A. Söllner, Zur Vorgeschichte und Funktion der actio rei uxoriae Köln-Wien 1969. Tok rozumowania A. Söllnera jest mniej więcej taki: jeśli rozwód nastąpi $\mathrm{z}$ winy żony, mężowi przysługują wtedy różne, w zależności od okoliczności, potrącenia, retentiones. $\mathrm{Z}$ drugiej strony, jeśli rozwód zawini mąż, musi posag wydać. Zatem $w$ interesie obojga, zdaniem Söllnera (s. $114 \mathrm{nn}$. 157), leży, by małżeństwo utrzymać. „Die heute vorherrschende Auffassung von der römischen Ehe, als einem freien Zusammenleben, das nur durch die Bande der Sitte und der Moral zusammengehalten worden sei, bedarf einer Korrektur. Das römische Dotalsystem bewirkte vermutlich eine ungleich stärkere Bindung der Ehegatten als die sanktionslose Rechtspflicht zur ehelichen Lebensgemeinschaft im geltenden Recht" konkluduje (157) Autor. 
$\mathrm{Na}$ przełomie starych i nowych czasów uległa rozluźnieniu tutela muliebris. Zdecydowany cios zadał tej instytucji August wprowadzając awantaże ius trium vel quattuor liberorum a także lex Claudia znosząca tutelę agnatów. Przez cały okres prawa klasycznego jest tutela muliebris $\mathrm{w}$ regresie ${ }^{15}$. Dioklecjan normuje ją jeszcze swymi konstytucjami ${ }^{16}$, ale $w$ tym czasie mocno zaawansowany jest już inny proces. Mianowicie opiekę nad dziećmi coraz częściej sprawuje ich matka ${ }^{17}$.

Głębokim przemianom w procesie przedklasycznym i klasycznym uległo stanowisko filius familias. Wprawdzie Gaius w drugim wieku pisze jeszcze, że ,qui in potestate est, nihil suum habere potest" 18, ale stwierdzenie to ma jedynie charakter zasady generalnej. Filio familias przyznano bowiem stosunkowo wcześnie czynną zdolność majątkową $\mathrm{W}$ zakresie peculium a patre profectum ${ }^{19}$. W granicach tego peculium występował on $\mathrm{w}$ obrocie prawnym na równi z sui iuris. Jeszcze dalej sięgały jego prerogatywy odnośnie peculium castrense, gdzie przynajmniej od czasów cesarza Augusta przyznano mu możność swobodnego testowania. Charakter peculiarny tego, co filius familias in castris adquisivit, manifestował się jedynie na przypadek beztestamentowej śmierci. Poza tym jednym ograniczeniem, majątek taki stanowił patrimonium filii, co do którego on vice patris fungitur. Jurysprudencja, cesarze Hadrian i Sewerowie tę instytucję rozbudowywali dalej 20.

Do zanotowania są także innowacje na polu prawa procesowego. Proces formułkowy zerwał mianowicie z zasadą, że filius familias nie może występować jako strona procesowa. „Toteż w czasach klasycznych pisze S. Wróblewski - spotykamy go często przed sądem, a choć edykt pojmuje go jako zastępcę ojca, to przecież występuje on nie tylko w imieniu własnym, ale $z$ reguły $w$ obronie własnego interesu, gdy np. dochodzi zwrotu pieniędzy danych w depozyt lub tytułem pożyczki bawiąc $\mathrm{w}$ mieście legationis vel studiorum gratia. A chodzi o to ne egestate Romae laboret, viaticulo suo non recepto, quod ad sumptum pater ei destinaverat" 21.

1.5 E. Sachers, RE 7A szp. 1589 n.: M. Kaser. RPR 12,369.

16. Tak się wydaje, konstytucje Dioklecjana zachowane $w$ Fr. Vat. 325 i 326 (z r. 293 ) są ostatnimi aktami, które te instytucje regulują. Por. E. Sachers, dz. cyt., szp. 1598 n.; M. Kaser. RPR 2. 158.

Por. G. Crifo, Sul problema dello donna tutrice in dirictto romano classico (BIDR 57, Milano 1965, $87 \mathrm{nn}$.). Do praktyki prowincjonalnej na wschodzie por. R. Taubenschiag, The Law of Greco-Roman Egypt in the Light of the Papyri, Warszawa 1955², 149 nn.; L. Wenger, Die Quellen des römischen Rechts, Wien 1953, 818 z wykazem źródeł i lit.

18 Gai. 2,87 por. także Gai. 2,96.

19 Por. M. Kaser, RPR $1^{2} .344$ i tam cyt. źródia i lit.

20) Por. F. La Rosa, I peculii speciali in diritto romano, Milano 1953, 19 nn., 61 nn.; nowsza lit. zestawiona u M. Kasera, dz. cyt., 344 n.

:1 S. Wróblewski, Zarys wykładu prawa rzymskiego, Kraków 273. 
W interesie dzieci sub patria potestate uległy przemianom normy prawa spadkowego. Zwracamy tutaj uwagę na querela inoficisi testamenti ${ }^{22}$. Nie pozwalała ona ojcu przejść do porządku dziennego nad swymi dziećmi; nie pozwalała bez naruszenia officium pietatis pozostawić ich bez zaopatrzenia. Querela inofficiosi testamenti jest dla nas ważna, bo jest emancją poglądów społecznych, dowodem na coraz to silniejsze przepieranie się w systemie prawa związków kognatycznych. Związków, których wagę już wcześniej dostrzegli pretorzy wprowadzając do swego edyktu o dziedziczeniu ob intestato grupę unde cognati.

Dalszą, jakże istotną, innowacją było Senatus consultum Orficianum ${ }^{23}$. Dopuściło ono dziedziczenie cywilne $a b$ intestato dzieci po matce. SC Orficianum było ukoronowaniem działalności pretorów, skoro oni już wcześniej wprowadzili bonorum possessio ab intestato odnośnie majątku pozostawionego przez matkę. J. Dénoyez ${ }^{24}$ w analizie tytułu Digestów 5.3 de hereditatis petitione, a w szczególności responsum Scaewoli (D. 5.3.58), zwraca uwagę na wysiłki jurysprudencji $\mathrm{w}$ tym czasie, które zmierzały do tego, by majątek po matce dostał się $\mathrm{w}$ ręce dziecka także wtedy, kiedy ono jest sub patria potestate. Tym tendencjom wyszedł naprzeciw jeden z reskryptów cesarza Sewera, który w pewnych wypadkach dawał możliwość zmuszenia ojca do emancypacji dziecka po to, by ono jako sui iuris mogło nabyć bona materna ${ }^{25}$. Warto zaznaczyć, że na podstawie $S C O$ do dziedziczenia byli powoływani tak syn jak córka, że na równi powoływało ono dzieci z różnych małżeństw i także na równi dzieci ex iusto matrimonio i vulgo quesiti ${ }^{26}$. Konstantyn przyznaje dzieciom in patria potestate własność na bona materna, zastrzegając ojcu użytkowanie i administrację ${ }^{27}$. Następcy Konstantyna obejmują tymi regułami bona materni generis a Justynian rozszerza je na wszystkie nabytki syna nie pochodzące ex re vel substantia patris. Prawo poklasyczne jest, jak widać, kontynuacją procesu zapoczątkowanego wcześniej w prawie klasycznym, a mającego na celu coraz dalej idącą ochronę interesów majątkowych dziecka.

Protekcja interesów materialnych dzieci ze szczególną siłą dochodzi do głosu w kształtowaniu przez prawo klasyczne instytucji tutela impuberis i cura minoris. Tutela impuberis jeszcze w czasach Cycerona poj-

22 Por. M. Kaser, dz. cyt., 710 z wykazem źródeł i lit.

23 Por. nade wszystko M. Meinhart, Die Senatusconsulta Tertullianum und Orfitianum, Graz-Wien-Köln 1967, 66 nn., 139 nn.

24 Por. J. Dénoyez, Les ,bona materna" a la lumière du D. 5.3, w: Droit de I'Antiquité et sociologie juridique, Mélanges Henri Lévy Bŕtuhl, Paris 1959, 77 nn.; M. Humbert, dz. cyt., $226 \mathrm{nn}$.

${ }_{25}$ Por. D. 35.1 .92$, ,...] ex auctoritate divi Severi emancipare eos [scil. dzieci] compulsus est hisque restituere hereditatem".

26 Por. M. Meinhart, dz. cyt., 142.

27 Por. CT 8.18.1 i do tego M. Kaser, RPR 2, $154 \mathrm{n}$. 
mowana była jako honor 28; prawo wczesnego okresu klasycznego pojmowało ją jako munus privatum ${ }^{29}$, a jurysprudencja epoki Sewerów (Papinian, Ulpian, Paulus ${ }^{30}$ ) już jako munus publicum. E. Sachers ${ }^{31}$ pisze: „Die Vormudschaft ist in stätklassischer Zeit ein Pflichtamt geworden, das im alleinigen Interesse des Mündels ausgeübt wird". Jest zrozumiałe, że interesy majątkowe impuberis największych szkód doznać mogły ze strony lekkomyślnego lub wręcz nieuczciwego tutora. Nic też dziwnego, że w miarę jak prawo interesy dziecka wysuwało na coraz pocześniejsze miejsce, sięgało równocześnie po coraz to nowe środki procesowe służące impuberis, zacieśniało granice swobodnego działania tutora i nade wszystko poszerzało jego odpowiedzialność majątkową. Tutor został poddany kontroli urzędowej; jego pozycja była wprawdzie stale określana domini loco, vice domini, tutelam gerere, administrare, ale treść tych określeń zmieniła się zupełnie ${ }^{32}$. W czasach Sewerów tutor jest już tylko tym, który pupila reprezentował. Prawo nie traktowało go już jako właściciela, a tylko posiadacza cudzego majątku. Wcześniej, bo za Trajana, nałożono na niektórych tutorów obowiązek składania satisdatio rem pupilli salvam fore ${ }^{33}$. Dobrze znana oratio Severi z 195 roku zakazywała zbywania i obciążania zastawem praedia rustica vel suburbana ${ }^{34}$. Zaostrzenie reżimu odpowiedzialności tutora objawiło się także przyznaniem pupilowi zastawu ustawowego na rzeczach nabytych przez tutora za pieniądze pupila ${ }^{35}$. Cesarze Severus i Caracalla zakazali tutorom, jak długo posiadają w swych rękach majątek pupilów, zawierania jakichkolwiek kontraktów z fiscus ${ }^{36}$. Chodziło o to, by przez egzekucję roszczeń fisci, któremu w tym czasie przysługiwała protopraxia, nie uszczuplić praw majątkowych pupila. W trzecim lub na początku czwartego wieku, ale jeszcze przed Konstantynem, przyznano pupilowi hipotekę generalną na majątku tutora ${ }^{37}$.

28 Cic. pro Sestio 111, pro Cluentio 41.

29 Por. Call. 1. quarto de cogn. D. 27.1.17.4.

30 Por. D. 50.5.8.4; D. 50.6.4; D. 50.5.12.1. Opieka pojmowana jest również jako officium, por. F. Cancelli, Saggio sul concetto di officium in diritto romano, Milano 1958, 12 n. 36 nn.

31 Dz. cyt., szp. 1500.

32 Por. E. Sachers, dz. cyt., szp. 1545 i tam zestawione źródla.

33 Por. D. 46.6; por. do tego tytułu E. Sachers, dz. cyt., szp. 1169 n.; M. Kaser, RPR $1^{2}, 364 \mathrm{n}$.

34 Por. D. 27.9 .1 pr. 3: „Imperatoris Severi oratione prohibiti sunt tutores et curatores praedia rustica vel suburbana distrahere. 1 Quae oratio in senatu recitata est Tertullo et Clemente consulibus idibus Iuniis et sunt verba eius huiusmodi: 2 ,Praeterea, patres conscripti, interdicam tutoribus et curatoribus, ne praedia rustica vel suburbana distrahant, nisi ut id fieret, parentes testamento vel codicillis caverint."

${ }_{35}$ Pcr. H. Derenburg, Das Pfandrecht 1, Leipzig 1860, 321 nn.: E. Sachers, dz. cyt., szp. 1572 .

${ }_{36}$ Por. H. Dernburg, Das Pfandrecht, $358 \mathrm{mn}$. P. Frezza, Le garanzie delle obligazioni. Le garanzie reali, Padova 1963, $262 \mathrm{nn} ., 120 \mathrm{n}$.

37 Por. H. Dernburg, dz. cyt., 362 n.; E. Sachers, dz. cyt., szp. 1572. 
Po dojściu pupila do dojrzałości ustaje opieka, a dojrzały uzyskuje w dawnym prawie rzymskim pełną zdolność do działania. Dojrzały mógł zawrzeć związek małżeński, sporządzić testament, samodzielnie brać udział w obrocie prawnym, podejmując osobiście różne akty prawne. Właśnie udział w obrocie krył w sobie dla dojrzałego, ale nie zawsze jeszcze życiowo doświadczonego, duże niebezpieczeństwa. Nasilenie tych niebezpieczeństw przyszło wraz z burzliwym rozwojem gospodarczym na przełomie trzeciego i drugiego wieku, kiedy Rzymianie szybko przekształcili się ze społeczeństwa agrarnego w społeczeństwo handlowe i ,przemysłowe", a samo miasto w metropolię calego świata. Zwraca uwagę Stanisław Wróblewski ${ }^{38}$, że mores maiorum straciły swe dawne znaczenie, a zmiana obyczajów i rozkwit lichwy i spekulacji otwarły drogę wyzyskowi młodzieży. Środkiem zaradczym stało się plebiscitum, uchwalone na początku drugiego wieku na wniosek prawdopodobnie trybuna ludowego Pletoriusa lub Laetoriusa, które było skierowane przeciw circumscriptio adulescentium ${ }^{39}$. W dalszym ciągu ochronę owych dojrzałych lecz nieletnich (minores viginti quinque annis) biorą $\mathrm{w}$ swe ręce pretorzy, jurysprudencja i cesarze. Z lex Plaetoria (Laetoria) wiąże się powstanie instytucji curator minoris, ustanawianego początkowo a casu ad casum na wniosek zainteresowanego, a także zapewne na wniosek jego bliskich. W drugim i trzecim wieku ustanawianie curator minoris stało się regułą ${ }^{40}$. Regułą stało się też, że kuratorzy przekształcili się w zarządców generalnych majątku minoris. Ustanowienie kuratora nie ograniczało jednakże w zdolności niedojrzałego, w związku z czym jedne czynności zawierane były przez niego samego consensu curatoris inne przez samego kuratora. Ale i w pierwszym i drugim wypadku kurator przejmował odpowiedzialność za to, co się działo. Uzasadniane to było względami na certitudo w obrocie, a także względami na interesy nieletniego. Skoro kuratela stała się regułą, zbliżenie się sytuacji prawnej niedojrzałych do sytuacji prawnej nieletnich nie dało na siebie długo czekać. Niwelację różnic przyspieszały wpływy praw hellenistycznych, które nie znały ostrej różnicy między małoletnim a niedojrzałym ${ }^{41}$. Reszty dokonała praktyka codzienna. Wszak do pomyślenia jest sytuacja, że ktoś zamianowany tutorem, po osiągnięciu przez pupila dojrzałości, pełnił nadal zarząd majątkiem już w charakterze kuratora. Jakoż w ciągu trzeciego wieku mnożą się normy prawne, które dotyczą tak tuteli jak ku-

: Zarys. 288.

39 Por. G. Rotondi, Leges publicae populi Romani (Milano 1912, przedruk: Darmstadt 1962) 271 i tam dalsza lit.

40 Por. M. Kaser, RPR 12, $370 \mathrm{n}$.

4 Por. L. Mitteis, Reichsrecht und Volksrecht, Leipzig 1891, 154 nn.; idem, Grundzüge, Leipzig 1912, 248 n. 251 nn.: S. Wróblewski, dz. cyt., 288 n. L. Wenger, Die Quellen des römischen Rechts, 817 n.; Tabenschlag The Law ${ }^{2}$, 157 nn.; M. Kaser, RPR 1², $352 \mathrm{n}$. 
rateli ${ }^{42}$. Jeśli w IV i V wieku cesarze stanowią, że vidua (CJ 5.4.18) lub virgo (CJ 5.4 .20 pr.) ${ }^{43}$ sui iuris ale intra XXV annorum muszą na zawarcie związku małżeńskiego lub jego ponowne zawarcie uzyskać zgodę ojca, w braku ojca zgode matki lub innych bliskich krewnych, to widzimy w tym fakcie rezultat zblizenia si@ sytuacji prawnej osoby nieletniej sui iuris do sytuacji prawnej osoby nieletniej sub patria potestate. Wymowna jest w tym względzie także konstytucja Gracjana, Walentyniana i Teodozjusza z r. 380, która jednakowo traktuje sive pupillae sive apud patres virgines sive viduae erunt, sive et sui iuris viduae ${ }^{44}$.

Sporo miejsca poświęciła rzymska iurysprudencja temu, ,qui in utero est, qui nasci speratur" 45. Nierzadko opinie prawników są w tym względzie nacechowane giębokim humanizmem. Cessus powiada ,,[...] conceptus quodammodo in rerum natura esse existimatur" 46 i tym samym wyprzedza znane sformulowanie Tertuliana , ,[...] homo est et qui futurus" ${ }^{47}$. Symptomatyczne, że w prawie rzymskim klasycznym dla ustalenia status libertatis, civitatis i przynależności do rodziny miarodajny był w iustum matrimonium nie moment urodzenia dziecka, lecz moment jego poczęcia ${ }^{48}$. Największymi atoli zdobyczami pretora i jurysprudencji jest jednak rozbudowa praw spadkowych nasciturus oraz stworzenie instytucji, które zabezpieczały realizację tych praw. Mamy na myśli missio in possessionem ventris nomine ${ }^{49}$ a także edictum de inspiciendo ventre custodiendoque partu ${ }^{50}$.

W toku naszych dotychczasowych wywodów chcieliśmy zwrócić uwagę na to, że rodzina rzymska w epoce klasycznej prawa, a zwłaszcza w drugim wieku, doznała głębokich przeobrażeń. Agnacja utraciła swe dawne znaczenie, choć strzępy jej usunął dopiero Justynian. Na plan pierwszy wysunęły się związki kognatyczne. Osłabła patria potestas. Poszczególni członkowie rodziny, wyemancypowani spod władzy pater familias, uzyskali daleko idącą samodzielność w zakresie praw osobowych,

4: Por. nade wszystkich M. Kaser, RPR 1², 353 i 2, $158 \mathrm{nn}$.

43 Por. do obu konstytucji M. Kaser, RPR 2, 111 uw. 10.

44 CJ 5.7.1. pr.

45 Podane i podobne określenia wyrażają spec nascendi, por. M. Bartošek, RIDA 2 (1948), $24 \mathrm{nn}$.

46 D. 38.16.7; wypowiedź ta występuje w aspekcie ewentualnych praw spadkowych, por. M. Meinhard, D. 50.16.231. Ein Beitrag zur Lehre vom Intestatserbrecht des ungeborenen Kindes (ZSS 82 (1965) 209) z powołaniem dyskusji między F. de Robertis i A. Steinwenter w ZSS 56 (1936), $380 \mathrm{n}$.

${ }_{47}$ Apol. 9. fraza jest użyta przez Tertuliana w znaczeniu moralno-teologicznym, por. M. Meinhardt, art. cyt., 209; B. Biondi, Il diritto romano chrisistiano, $3,488$.

48 Por. Gai. 1,89, ,[...] hi, qui legitime concipiuntur ex conceptionis tempore statum sumunt"; por. Mi. Bartošek, art. cyt., 24 nn.; M. Meinhardt, art. cyt., 198.

49 Por. M. Kaser, RPR 1², 699 ze źródłami i lit. w uw. 20.

50 Tekst edyktu w D. 25.4.1.10 przedrukowany u O. Lenala, Edictum perpetuum, Leipzig 19273, 312 n.: A. Metro, La datazione dell'editto de inspiciendo ventre custodiendoque partu (Synteleia V. Arangio-Ruiz 2, Napoli 1964, 944 nn.) i tam dalsza lit. 
a przede wszystkim majątkowych. Szczególną troską i opieką otoczyło prawo interesy majątkowe dzieci. Instytucja tuteli, kurateli, a także normy prawa spadkowego, uległy daleko idącym przeobrażeniom w interesie właśnie dzieci $\mathbf{5 1}$.

Legislatorzy późnego cesarstwa, jak w wielu innych wypadkach, nie ty.ko nie odstąpili od linii rozwojowych, jakie w naszej materii zarysowały się w ciągu drugiego i na początku trzeciego wieku, lecz dzieło pretorów i jurysprudencji kontynuowali na wszystkich frontach. Obserwuje się to w prawie spadkowym, gdzie na różne sposoby utwierdzana jest zasada, że majątek zmarłego winien przypaść najbliższym kognatom, przede wszystkim dzieciom. W prawie opiekuńczym tutor i kurator poddani są w interesie dzieci coraz silniejszej kontroli urzędowej. Swoboda dysponowania majątkiem pupila już w czasach Konstantyna doznała dalszych istotnych ograniczeń.

Konstytucje zebrane w rubrykach de secundis nuptiis, a także te, które w innych rubrykach kodeksów zajmują się powtórnym małżeństwem, są jedynie fragmentem ogółu przepisów, które interesy dziecka zabezpieczały.

W tych konstytucjach na plan pierwszy wysuwają się następujące sprawy:

1) Kobieta wstępująca w ponowne związki małżeńskie nie może sprawować opieki nad dziećmi z pierwszego łoża 52. Daty powstania tego zakazu nie znamy. Z dużą dozą prawdopodobieństwa można przypuszczać że został on sformułowany w pierwszej połowie drugiego wieku, że pochodzi on $z$ tych samych dni, w których kobieta, naturalnie w sytuacjach wyjątkowych, została dopuszczona przez prawo do sprawowania opieki

51 Wspomnieć by tu można jeszcze rozwój obowiązku alimentacyjnego. Za Cycerona alimenty obejmowały cibus potus, victus, a za Ulpina wszystko, co ,[...] ad vivendum homini necessaria sunt" (D. 50.16.43); por. na ten temat F. Wycisk, Pojęcie alimentów w rzymskim prawie klasycznym (1968) maszynopis s. $50 \mathrm{nn} .91 \mathrm{nn}$. (praca niepublikowana). I w tym zakresie dzieci stały się przedmiotem troski jurysprudencji i cesarzy; por. E. Sachers, Das Recht auf Unterhalt in der römischen Familie (Festschrift F. Schulz 1, Weimar 1951, 319 nn.). Następnie wskazać by można na ograniczanie przez prawo klasyczne ius vendendi ojca w stosunku do dzieci, por. E. Sachers, RE s. v. patria potestas, szp. 1098; Th. Mayer-Maly, Das Notverkaufsrecht des Hausvaters (ZSS 75 (1958) $116 \mathrm{nn}$.). Wymowna jest tutaj konstytucja Dioklecjana i Maksymiana z r. 294 (CJ 4. 43.1): "Liberos a parentibus neque venditionis neque donationis titulo neque pignoris iure aut quolibet alio modo, nec sub praetextu ignorantiae accipientis in alium transferri posse manifesti iuris est".

52 Pytanie, czy w prawie klasycznym matka może sprawować opiekę nad swymi dziećmi, jest w literaturze żywo dyskutowane. Na początku bieżącego stulecia większość romanistów utrzymywała, że matka do opieki nad dzieckiem została dopuszczona dopiero w okresie poklasycznym. Źródła, które by przemawiały za pojawieniem się matki opiekunki w czasach klasycznych, podejrzewano o interpolacje. Jestem przekonany, że G. Crifò w swoim studium Sul problema della madre tutrice in diritto romano classico $\mathrm{w}$ sposób przekonywujący dowiódł klasyczności tych tekstów (BIDR 67 (1965) 87 nn.). 
nad swymi dziećmi ${ }^{53}$. Rzymianie wierzyli, że nikt nie może być lepszym wychowawcą dzieci, niż ich własna matka ${ }^{54}$. W powierzeniu jej opieki nad dzieckiem mieli jednak duże opory. Przeświadczenie, że opieka ...plerumque virile officium est, że tutela ...munus masculorum est, utrzymuje się przez cały drugi wiek. Ale i w czasach Sewerów opory powierzenia matce opieki zapewne były jeszcze mocno determinowane tradycją historyczną ${ }^{55}$. Przez tyle wieków była wszak mulier sui iuris sama poddawana opiece. Nic też dziwnego, że prawo dopuściwszy pewnego dnia matkę do sprawowania opieki nad jej własnym dzieckiem, nałożyło na nią równocześnie warunek, że nie zawrze ponownego małżeństwa. Warunek jest najzupełniej usprawiedliwiony. Matka-opiekunka ma wobec dziecka podwójne obowiązki. Swoje matczyne i ojcowskie. Czy z tak poważnych obowiązków byłaby w stanie wywiązać się kobieta, która zawiera ponowne małżeństwo i musi się liczyć z tym, że w przyszłości przyjdzie jej wychowywać potomstwo z drugiego związku? Na pewno nie. Konstantyn w konstytucji ${ }^{56}$ ograniczającej tutorów w swobodzie alienacji majątku pupila, nowo wprowadzonym rygorom poddał także mat-

53 Materna potestas wykształciła się w Rzymie na początku drugiego wieku. Neratius w liber III regularum (D. 26.1.18) pisze: „Feminae tutores dari non possunt, quia id munus masculorum est, nisi a principe filiorum tutelam specialiter postulent". Wynika z tego, że w czasach Trajana - Hadriana, matka, by zostać opiekunem własnych dzieci, musiała dokonać specjalnej postulatio u cesarza. Ową postulatio lub też petitio tutelae reguluje następnie dokładniej konstytucja Valentyniana, Teodozjusza i Arkadiusza z r. 390 (CT 3.17 .4 pr i 4). Wymowne dla nas jest stwierdzenie Gaiusa (1. XII ad ed. prov. D. 26.1 .16 pr): „Tutela plerumque virile officium est”. Plerumque wskazuje, że najczęściej opiekę sprawują mężczyźni, ale nie tylko oni. Z postulatio tutelae ma również związek responsum Papiniana D. $26.2 .26 \mathrm{pr}$ : ,Iure nostro tutela communium liberorum matri testamento patris frustra mandatur, nec, si provinciae praeses imperitia lapsus patris voluntatem sequendam decreverit, successor eius sententiam, quam leges nostrae non admittunt, recte sequetur". Fragment ten obrósł już w bogatą literaturę (referuje ją G. Crifò, dz. cyt., 106 n.). Uczeni są podzieleni tak co do interpretacji, jak i co do wniosków, jakie w oparciu o wypowiedź Papiniana snuć można. Naszym zdaniem, źródło nie daje podstaw do twierdzenia, że Papinian nie dopuszczał opieki matki nad dzieckiem, a jedynie, że ustanowienie matki opiekunką w testamencie przez męża i ojca jest daremne. Jest ono nieważne nawet wtedy, jeśliby prezes prowincji wskutek imperitia matkę jako opiekunkę dzieci zatwierdził. Imperitia prezesa prowincji nie może tyczyć nieznajomości praw prowincjonalnych, hellenistycznych, bo tam matka od wieków mogła sprawować opiekę nad własnymi dziećmi (por. P. Taubenschlag, Materna potestas im gräko-agyptyschen Recht (ZSS 49 (1929) 115 nn.); tenże Law2, 149 nn.; L. Wenger, Quellen, 816 nn.; G. Crifò dz.. cyt., 101 i dalsza lit. w uw. 43). Imperitia dotyczyła nieznajomości trybu postępowania w takim wypadku wedle prawa rzymskiego. Matka powinna złożyć postulatio tutelae u cesarza, a nie u prezesa prowincji. Ten ostatni zatwierdzając matkę jako opiekunkę przekroczył swoje kompetencje i wszedł w kompetencje samego cesarza. Naturalnie tekst Papiniana można uznać za interpolowany i interpretować w inny sposób.

54 Por. nade wszystko M. Humbert, dz. cyt., $296 \mathrm{nn}$.

55 Por. CJ 5.35.1 Imp. Alexander A. Octaciliae. Tutelam administrare virile munus est, et ultra sexum feminae infirmitatis tale officium est (a. 224). Por. do tej konst. wywody G. Crifò, dz. cyt., 115 nn.

56 CJ 5.37.22 (Constantinus ad populum, a. 326 ). 
kę-opiekunkę ${ }^{\mathbf{5 7}}$. Z tej konstytucji wynika jednakże, że zakaz zawierania przez matkę-opiekunkę nowego związku małżeńskiego był mu dobrze znany. Na nowo zajęli się tą sprawą cesarze Walentynian, Teodozjusz i Arkadiusz z r. $390^{58}$. Stanowią oni w pierwszym rzędzie, że jeśli matka ubiega siẹ o objęcie opieki nad dzieckiem, winna złożyć zapewnienie, zanim w takim charakterze zostanie zatwierdzona, że nie zawrze ponownego związku małżńskiego ${ }^{29}$. Konstytucja podkreśla pelne prawo wyboru, jakie kobiecie przysługuje: opieka nad dzieckiem lub powtórne małzeństwo. Zauważyć wszakże wypada, że alternatywę: być opiekunką dzieci i równocześnie zrezygnować z ponownego zamążpójścia lub nie podejmować opieki i mié́ możność zawarcia drugiego małżeństwa - przedstawili cesarze kobiecie w sposób bardzo sympatyczny: ,Sane in optione huiusce modi nulla cogitur, sed libera in condiciones quas praestituimus voluntate descendat; nam si malunt optare alia matrimonia, tutelas filiorum administrare non debent" 60. Wreszcie, jeśli kobieta-opiekunka, nie bacząc na złożone przyrzeczenie, zawarłaby nowy związek małżeński, drugi mąż będzie $z$ nią razem odpowiedzialny majątkowo za wszelki uszczerbek, jaki w majątku pupila może powstać ${ }^{61}$.

W zakazie sprawowania opieki nad dzieckiem przez matkę powtórnie zamężną nie widzimy dezaprobaty ponownego małżństwa. Widzimy raczej głęboką mądrość cesarzy, którzy bogaci w doświadczenia całych generacji wiedzieli, że matka ponownie zamężna, gdyby przy niej pozostawić opiekę nad dziećmi z pierwszego łoża, mogłaby nadmiarowi obowiązków nie podołać. Z drugiej strony dzieci, które straciły już ojca, mogłyby w takiej sytuacji pozostać bez żadnej opieki ${ }^{62}$. Postanowienie

57 CJ 5.37.22.5: „Lex enim non solum contra tutures, sed etiam contra feminas immoderatas atque intemperantes prospexit minoribus, quae plerumque novis maritis non solum res filiorum, sed etiam vitam addicunt". Por. G. Crifò, dz. cyt.. $91 \mathrm{n}$.

5. CT 3.17.4. = CJ 5.35.2, por. G. Crifò, dz. cyt., 88 nn.; tenże, Rapporti tutelari nelle novelle giustinianee, Milano 1965, 99.; M. Humbert, dz. cyt., 410 nn. i tam dalsza lit.

59 Pr.: „Matres, quae amissis viris tutelam administrandorum negotiorum in liberos postulant, priusquam confirmatio offici talis in eas iure veniat, fateantur actis ad alias se nubtias non venire". Interpretatio tej części konstytucji brzmi: ,Mulieres mortuis maritis, si ipsae voluerint tutelam suscipere filiorum, priusquam hoc adsumant, actis profiteantur se non esse nubturas".

60 Pragniemy zwrócić uwagę na dwa wyrażenia w tej konstytucji: Nulla cogitur i libera voluntas, którą winna się kierować kobieta przy podejmowaniu decyzji.

61 \& 2: ,Sed ne sit facilis in eas post tutelam iure susceptam inruptio, bona eius primitus, qui tutelam gerentis affectaverit nubtias, in obligatione venire et teneri obnoxia rationibus parvulorum praecipimus, ne quid incuria, ne quid fraude depereat", i do tego interpretatio: ,Sciant hoc etiam viri, qui sibi iungendas matres postulant parvulorum, quod, si mulieres tutelam administrare coeperint et postea nubserint, ille, qui in consortium recipitur maritale, bona sua noverit obligata et se ad rationem reddendam minoribus obnoxium esse futurum".

62 Jakże plastycznie widział takie sytuacje Konstantyn, skoro pisał (feminae immoderatae atque intemperantes)..., quae plerumque novis maritis non solum res filiorum, sed etiam vitam addicunt" (por. caly tekst w uw. 57). 
o współodpowiedzialności małżonka z drugiego małżeństwa za uszczuplenie majątku dzieci z pierwszego łoża utwierdza nas w przekonaniu, że u podstaw prawno-politycznych całej konstytucji legła nie chęć zakazu drugiego malzeństwa, lecz interesy majątkowe dzieci.

2) Drugą kwestią, którą kontemplują nasze konstytucje (a zwłaszcza CJ 5.9.3 i 5) jest, że pozostały przy życiu małżnek w przypadku zawarcia nowego związku małzeńskiego traci na rzecz dzieci z pierwszego małzeństwa wszystkie przysporzenia majątkowe, jakie otrzymał od małżonka zmarłego. Małzonkowi wstępującemu w nowe związki małzeńskie przysiuguje w odniesieniu do tej masy majątkowej tylko possessi ac ius fruendi in diem vitae ${ }^{63}$. Zasada ta jest przedstawiona w postaci bardzo szczegółowych przepisów, nie zawsze zupełnie jasnych i nie zawsze konsekwentnych. Drobiazgowo są wyliczane elementy składowe majątku. Tak np. w konstytucji z 382 Gracjan, Walentynian i Teodozjusz stanowią (CJ 5.9.3): „Feminae quae susceptis ex priore matrimonio filiis ad secundas, post tempus luctui statutum transierint nuptias, quidquid ex facultatibus priorum maritorum sponsalium iure, quidquid etiam nuptiarum sollemnitate perceperint, aut quidquid mortis causa donationibus factis aut testamenti iure directo aut fideicomissi vel legati titulo vel cuiusliber munificae liberalitatis praemio ex bonis, ut dictum est, priorum maritorum fuerint adsecutae, id totum, ita ut perceperint, integrum ad filios, quos ex praecedente coniugio habuerint, transmittant vel ad quemlibet ex (dummodo ex his tantum, quos tali successione dignissimos iudicamus), in quem contemplatione meritorum liberalitatis suae iudicium mater crediderit dirigendum". Dalej określany jest sposób administracji takim majątkiem, a także zasady, jakie będą obowiązywać przy dziedziczeniu, na przypadek jeśli dziecko, lub jeđno z dzieci, umrze. Nie będziemy się wdawać w analizę tych przepisów, gdyż wykraczałoby to poza ramy i cel niniejszej pracy. Ograniczymy się jedynie do ustalenia motywów, które przypuszczalnie inspirowały cesarzy przy promulgowaniu tych norm. Wspominaliśmy już wyżej, że rozwój klasycznego prawa spadkowego charakteryzował się manifestującą się na różne sposoby tendencją, by dziedziczenie po rodzicach zapewnić dzieciom. Tym pryncypiom, tej tendencji hołdują także cesarze chrześcijańscy. Jak długo majątek pozostaje w rękach rodziców lub w rękach jednego z rodziców, tak długo dzieci mają naturalną ekspektatywę, że ten majątek przypadnie im w drodze spadkobrania. Sytuacja zmienia się, kiedy pozostały przy życiu małżonek wstępuje w nowe związki małżeńskie. Jeśli w takiej sytuacji nie musiałby on wydać majątku otrzymanego od zmarłego współmałżonka dzieciom z pierwszego łoża, dzieci z drugiego mał- 
żeństwa byłyby nadmiernie faworyzowane. One bowiem miałyby ekspektatywę na dziedziczenie nie tylko majątku własnego rodziców, ale także majątku, które jedno z nich otrzymało od małżonka w pierwszym małżeństwie. Dzieci z pierwszego małżenstwa byłyby w ten sposób niezasłużenie pokrzywdzone.

Tak więc i tutaj cesarze przy wydawaniu tych przepisów w najmniejszym stopniu nie kierowali się niechęcią do ponownego małżeństwa, ile zasadą słuszności, że drugie małżeństwo nie może uszczuplać praw majątkowych dzieci z pierwszego małżeństwa. Przyznając possesio ac ius fruendi wspomnianego majątku małżonkowi, który ponownie zawarł związek małżeński, a własność dzieciom z pierwszego łoża, wybrali cesarze rozwiązanie w tych warunkach optymalne. O braku niechęci cesarzy chrześcijańskich do ponownego związku małżeńskiego świadczy dobitnie okoliczność, że jeśli interes dzieci nie wchodzi w rachubę - pozostały przy życiu małżonek w przypadku ponownego zawarcia związku małżeńskiego nie tracił przysporzeń majątkowych dokonanych przez współmałżonka zmarłego ${ }^{64}$.

3) Ogromnie ciekawa dla naszej problematyki jest konstytucja cesarzy Walentyniana, Teodozjusza i Akradiusza z 392 r. przekazana w CJ 5.10.1, a zatytułowana: Si secundo nupserit mulier, cui maritus usum fructum relinquerit ${ }^{65}$. Przewiduje ona, że ususfructus ustanowiony na res suae przez zmarłego małżonka wygasa, jeśli żona zawrze nowy związek małżeński. Znów widzimy, jak cesarze manifestują tutaj swą troskę o dzieci z pierwszego małżeństwa. Stoją oni na stanowisku, że taki ususfructus ma charakter alimentacyjny ${ }^{66}$. Ma on zadanie zapewnić wdowie egzystencję materialną. Jeśli kobieta ponownie wyjdzie za mąż, causa, dla której ususfructus został ustanowiony, odpada. Od tego momentu taki ususfructus służyłby także drugiemu małżonkowi, a także i dzieciom z drugiego małżeństwa, jeśli się urodzą. Nie byłoby to zgodne z intencją zmarłego i z krzywdą dla dzieci z pierwszego małżeństwa. Także i w tym wypadku cesarze nie dają wyrazu jakiejś hostilitas do ponownego związku małżeńskiego. Zapobiegają jedynie, by przez zawarcie nowego mał-

64 Por. tekst CJ 5.9.3.2 na str. 2.

65 CJ 5.10.1; ,Si usum fructum maritus rerum suarum decedens uxori reliquerit eaque in secundas nuptias consortiumque convenerit, usum fructum, quem ex priore marito consecuta fuerit, amittat atque eum filis ex die quo nupserit mature restituat. $\S 1$ Quod si liberos ex priore matrimonio adhuc imbecillitas habebit infantiae nec muniet tutoris auxilium ac per huiusmodi occasionem mater que relicta fuerant usurpaverit, omnia, cum legitime repetantur, cum competentibus fructibus ad liquidum deducta ratione restituet. $\S 2$ Haec de usu fructu, quem vir extremam constituens voluntatem de rebus propriis uxori reliquerit". Por. M. Humbert, dz. cyt., 390 i tam dalsza lit.

66 Wypada zauważyć, że charakter alimentacyjny tzw. serwitutów osobistych jest w literaturze niedostatecznie oświetlony; por. E. Levy, West Roman Vulgar Law, Philadelphia 1951, 34 nn.; L. Anné, Les rites des fiançailles et la donation, Louvain 1941, 493. 
żeństwa dzieci z pierwszego związku nie poniosły przy tej okazji uszczerbku majątkowego.

4) Konstytucje Gracjana, Walentyniana i Teodozjusza z roku 380 i 381 (CJ 5.9.167 i 5.9.2. ${ }^{68}$ ) przewidują karę infamii i różne kary majątkowe, którym podlega kobieta, jeśli ,perdito marito inta anni spatium alteri festinavit innubere”, lub ,si qua mulier nequaquam luctus religionem priori viro nuptiarum festinatione praestiterit". Ale i tutaj kobieta jest karana nie za to, że zawarła drugi związek małżeński, lecz za to, że zawarła go za wcześnie ${ }^{69}$, nie przestrzegając tempus lugendi przewidzianego przez prawo ${ }^{70}$. Konstytucje te zdaniem naszym nie wnoszą żadnego argumentu za tezą o niechęci cesarzy do drugiego małżeństwa jako takiego.

Konkludując powiemy: nauka Ojców Kościoła nie wywarła wpływu na stosunek cesarzy chrześcijańskich do ponownie zawieranego związku małżeńskiego. W konstytucjach de secundis nuptiis samo małzeństwo jest na dalszym planie, na plan pierwszy wysuwa się troska cesarzy o szeroko pojęte interesy dzieci, jeżeli pozostały przy życiu małżonek wstępuje w ponowne związki małżeńskie. W swej polityce legislacyjnej w stosunku do dzieci kontynuowali cesarze linię polityki, zakreśloną przez jurysprudencję klasyczną. Polityka legislacyjna cesarzy i nauka Ojców

67 CJ 5.8.1: „Si qua mulier nequaquam luctus religionem priori viro nuptiarum festinatione praestiterit, ex iure quidem notissimo sit infamis. § 1 Praeterea secundo viro ultra tertiam partem bonorum in dotem ne det neque ei testamento plus quam tertiam partem relinquant. Omnium praeterea hereditatum legatorum fideicommissorum suprema voluntate relictorum, mortis causa donationum sit expers. haec namque $a b$ heredibus vel coheredibus aut ab intestato succedentibus vindicari iubemus, ne in his, quibus correctionem morum induximus, fisci videamur habere rationem. § 3 His etiam amittendis, quae prior maritus ei suprema reliquerit voluntate, quamquam haec, quae mulieri a priore viro relinquuntur et per immaturum matrimonium vacuata esse coeperunt, primo a decem personis edicto praetoris enumeratis, id est adscendentibus et descendentibus et ex latere usque ad secundum gradum, scilicet gradibus servatis, deinde praesumi a fisco iubemus. $\S 4$ Eandem quoque mulierem infamem redditam hereditates ab intestato, vel legitimas vel honorarias, non ultra tertium gradum sinimus vindicare". (a. 380).

68 CJ 5.9.2: „Si qua ex feminis perdito marito intra anni spatium alteri festinavit innubere (parvum enim temporis post decem menses servandum adicimus, tametsi id ipsum exiguum putemus), probrosis inusta notis honestioris nobilisque personae et decore et iure privetur atque omnia, quae de prioris mariti bonis vel iure sponsalium vel iudicio defuncti coniugis consecuta fuerat, amittat". (a. 381).

69 Por. W. Panecki, art. cyt., 261 n.

70 Obowiązek luctus tłumaczy się względami religijno-obyczajowymi i techniczno-prawnymi. Nieobserwowanie przez wdowę tempus lugendi może prowadzić do tzw. turbatio sanguinis, do niemożności ustalenia ojca dziecka. W różnych okresach ustawodawca brał w rachubę jako zasadniczy to jeden to drugi wzgląd. W prawie klasycznym, a taką zașadę wyznawali Pomponius i Ulpian, tempus lugendi wygasał, jeśli kobieta w czasie jego trwania urodziła, „Pomponius eam, quae intra legitimum tempus partum ediderit, putat statim posse se nuptiis collocare" (Uip. 1.6 ad ed. D. 3.2.11.2). W prawie poklasycznym przeważał znów wzgląd religijno-obyczajowy nad techniczno-prawnym. Por. P. Rasi, Tempus lugendi, w: (Scritti in onore di C. Ferrini, Milano 1 (1947) 393 nn.); M. Humbert, dz. cyt., 378: A. Berger, Encyclopedical Dictionary s. v. luctus i tam dalsza lit. 
Kościoła były tutaj zresztą w dużym stopniu zbieżne. Z pewną jednak różnicą. Podczas gdy nauka Kościoła do ponownego małżeństwa odniosła się niechętnie, dla cesarzy secundae nuptiae były obojętne: ani ich nie zalecali, ani ich nie deprecjonowali.

Tym samym nie twierdzimy, że Kościół nie wywierał i nie wywarł żadnego wpływu na ustawodawstwo cesarskie od czasów Konstantyna począwszy. Są jednak pewne kwestie, są pewne dziedziny, które tym wpływom się oparły albo do których te wpływy nie dotarły. Tak np. Kościół od samego początku przyjął za fundament swojej nauki o małżeństwie, że jest ono nierozwiązywalne ${ }^{71}$. Wielu uczonych uważa, że w tej kwestii wpływy nauki Ojców Kościoła były przeogromne. M. Kaser w swej syntezie pisze: „Wohl die starkste Einwirkung der christlichen Lehre auf das Privatrecht zeigt das Recht der Scheidung. Die Freicheit jedes Ehegatten, die Ehe jederzeit einseitig zu lesen, weicht in der staatlichen Ordnung zwar nicht vollstandig dem christlichen Dogma, das die Ehe zu Lebzeiten beider Gatten für unaufloslich erklärt; doch werden jetzt nur noch bestimmte Scheidungsgründe zugelassen" 72. Ale wywodzi dalej M. Kaser ${ }^{73}$ - rozwód dokonany $z$ innego, niż przewidziany w ustawie, powodu był ważny, a strona, która go przeprowadziła, była karana karami majątkowymi. To dlatego, że nauka Kościoła nie przeparła w systemie prawnym zasady o nierozwiązywalności małżeństwa. Konstantyn, jego następcy, a także Justynian stali na gruncie zasady, że małżeństwo jest rozwiązywalne ${ }^{74}$.

W świecie grecko-rzymskim spędzenie płodu było powszechnie praktykowane ${ }^{75}$. Poglądy stoików ${ }^{76}$, którzy uważali, że płód w łonie matki

71 Naukę Kościoła w tym zakresie, w oparciu o najnowszą literaturę, referuje J. Gaudemet, L'Église dans l'Empire Romain (IVe-Ve siècles), 540 nn., por. także B. Biondi, dz. cyt., 3, s. $151 \mathrm{nn}$.

I2. Kaser, RPR 2, 120 .

73 Por. dz. cyt., 121 nn.

74 Jean Gaudemet, bez wątpienia najwybitniejszy znawca historii Kościoła i prawa rzymskiego w IV i V wieku, doszedł w naszej kwestii do następującej konkluzji: „Quant à la législation séculiere, jamais elle n'interdira totalement le remariage duvivant du premier conjoint. Elle s'efforce de lutter contre l'abus du divorce en le limitant à certaines causes. Constantin, qui inaugure cette législation se montre particulièrment sévère. Il n'admet que trois causes de divorce en faveur de chacun des époux (dont l'adultère du conjoint). Une réaction si brutale était prématurée. Il fallut par la suite élargir la liste. Des mesures diverses se succédèrent, témoignages d'hésitation et sanse doute d'incuccès. Justinien tentera d'imposer une solution moyenne.

Dans tout cette législation l'influence de l'Église est certaine. Son échec partiel n'est pas moins évident. Non seulement elle ne put imposer sa loi d'indissolubilité absolue. Mais aucun des textes qui restreignent la faculté du divorce ne frappe de nullité le remariage conclus après divorce irrégulier. C'est donc que celui-ci, s'il expose à des peines, en général pécuniaires, n'est pas nul. Sur un point essentiel de l'organisation familiale, l'action de l'Eglise se soldait par un demi-succès". (L'Eglise dans L'Empire Romain, 545).

${ }_{75}$ Por. fundamentalną na ten temat prace E. Nardi, Procurato aborto nel mondo greco-romano, Milano 1971.

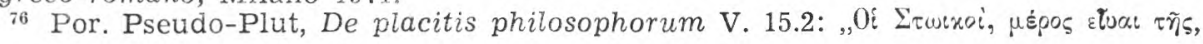


jest mulieris portio vel viscerum, takiej praktyce nie stawiały żadnej tamy. Reskrypt Septymiusza Sewera i Karakalli komentowany przez Trifoniusa ${ }^{77}$, Ulpiana ${ }^{78}$ i Marcjana ${ }^{79}$ karze kobietę spędzającą płód karą banicji. Ale $w$ ten sposób ochrony nie doznaje płód ${ }^{80}$ jako taki, a tylko interes eksmałżonka, którego kobieta w ten sposób pozbawia potomstwa. Ojcowie Kościoła IV i V wieku temu problemowi o ogromnej doniosłości moralnej i społecznej poświęcają wiele, wiele uwagi, głosząc, że spędzenie płodu stanowi homicidium ${ }^{81}$. Nie wywarło to żadnego wpływu na cesarzy chrześcijańskich. Podobnych przykładów można by dać więcej.

Chrześcijaństwo w czwartym i piątym wieku było jeszcze za słabe, by swymi wpływami przepoić wszystkie dziedziny życia współczesnego człowieka.

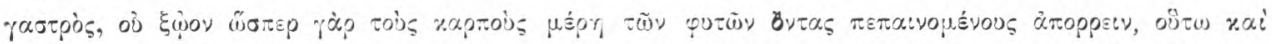

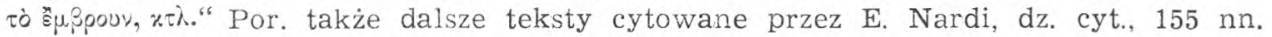
Co do ogólnego wpływu stoa na prawników rzymskich por. przede wszystkim M. Pohlenz, Die Stoa. Geschichte einer geistigen Bewegung, Göttigen 1959², 257 nn.; Jak dalece prawnicy podzielali poglądy stoików mogą świadczyć następujące wypowiedzi: Papinian, 1.19 quaest. D. 35.2.9.1: ,[...] quia partus nondum editus homo non recte fuisse dicitur"; Ulp. 1.24 ad ed. D. 25.4.1.1: ,[...] partus enim antequam edatur, mulieris portio est vel viscerum".

77 Por. D. 48.19.39: „,...] sed et si qua visceribus suis post divortium, quod praegnans fuit, vim intulerit, ne iam inimico marito filium procrearet, ut temporali exilio coerceantur, ob optimis imperatoribus nostris rescriptum est".

78 Por. D. 48.8.8: „Si mulierem visceribus suis vim intulisse, quo partum abigeret, constiterit, eam in exilium praeses provinciae exiget". Do tego fragmentu por. wywody E. Nardi, dz. cyt., 610 i tam dalsza lit.

79 D. 47.11.4: „Divus Severus et Antoninus rescripserunt eam, quae data opera abegit, a praeside in temporale exilium dandam: indignum enim videri potest impune eam maritum liberis fraudasse".

so Por. wywody E. Nardi, dz. cyt., $609 \mathrm{nn}$.

81 Por. E. Nardi, dz. cyt., 483 nn. z przeglądem i omówieniem źródeł, tudzież literaturą. 
DIE ZWEITE EHE IN DEN KONSTITUTIONEN DER RÖMISCHEN KAISER DES IV UND V JAHRHUNDERTS

Zus a m menfassung

In der Jurisprundez des römischen Rechtes gilt allgemein die Auffassung, dass die von den Kirchenvätern des II bis IV Jahrhunderts gebildete Lehre der Kirche einen überwiegenden Einfluss auf die Einstellung der nachklassischen Gesetzgeber (von Kaiser Konstantin an) zu einer zweiten Eheschliessung ausgebüt hätte.

Der Verfasser der Abhandlung ist der Ansicht, dass man zu weit geht, in der Einstellung der Kaiser zu einer zweiten Ehe Einflüsse des Christentums zu erblicken. In den Konstitutionen de secundis nuptiis steht nämlich die Sache der Ehe auf weitrem Plan; in erster Linie stellen die Kaiser, wenn der überlebende Ehegatte eine zweite Ehe eingeht, die Sorge um das weitgehend verstandene WohI der Kinder. In ihrer Gesetzgebungspolitik betreffs der Kinder folgen die Kaiser der von der klassischen Gesetzgebung vorgezeichneten Linie. In dieser Hinsicht stand übrigens die Gesetzgebungspolitik der Kaiser der Lehre der Kirchenväter in weitem Masse nahe. Doch gab es da einen Unterschied. Während die kirchliche Lehre zu einer zweiten Ehe eher negativ eingestellt war, standen die Kaiser einer zweiten Eheschliessung gleichgültig gegenüber, die secundae nuptiae waren von ihnen weder empfohlen noch als minderwertig geschätzt.

Der Verfasser will jedoch nicht jedweden Einfluss der Kirche in dieser Sache auf die Legislatur der nachklassischen Epoche negieren. 